\title{
Adult diffuse gliomas produce mRNA transcripts encoding EGFR isoforms lacking a tyrosine kinase domain
}

\author{
ANGÉLIQUE GUILLAUDEAU ${ }^{1}$, KARINE DURAND ${ }^{1}$, HÉLÈNE RABINOVITCH-CHABLE ${ }^{2}$, \\ ISABELLE POMMEPUY ${ }^{1}$, LAURA MESTUROUX ${ }^{1}$, SANDRINE ROBERT $^{1}$, ALAIN CHAUNAVEL ${ }^{1}$, \\ JEAN-JACQUES MOREAU ${ }^{3}$ and FRANÇOIS LABROUSSE ${ }^{1}$ \\ Departments of ${ }^{1}$ Pathology, ${ }^{2}$ Biochemistry and Molecular Genetics, ${ }^{3}$ Neurosurgery, \\ Dupuytren University Hospital, 2 Avenue Martin Luther King, F-87042 Limoges, France
}

Received August 24, 2011; Accepted September 27, 2011

DOI: 10.3892/ijo.2011.1287

\begin{abstract}
The epidermal growth factor receptor $(E G F R)$ gene encodes four alternatively spliced mRNA, variants $1,2,3$ and 4 , respectively, encoding the whole isoform a (EGFR) and truncated isoforms b, c and d, all of which lack the receptor's intracellular domain. In addition, a mutant EGFRvIII differs from isoform a in a truncated extracellular domain. The expression pattern of these isoforms is unknown in adult diffuse gliomas. Thus, we investigated in 47 cases: i) EGFR protein expression by immunohistochemistry using an extracellular domain-recognizing antibody (Ext-Ab) and an intracellular domain specific one (Int-Ab), ii) mRNA expression of EGFRv1, -v2, -v3, -v4 and -vIII by RT-PCR and iii) EGFR amplification by fluorescent in situ hybridization. The relation of these data with histological criteria and patient outcome was studied. The immunostaining was stronger with the Ext-Ab than with the Int-Ab. EGFRv1, -v2, -v3 and -v4 mRNA expression were highly correlated. They were expressed in all tumors, with highest levels in glioblastomas. EGFRv1 strong levels and the presence of vIII mRNAs were more closely associated with Int-Ab staining. EGFR gene amplification concerned only glioblastomas and was associated with the presence of EGFRvIII and high levels of EGFRv2, -v3 and -v4 transcripts. A pejorative outcome was associated with: histology (glioblastomas), $E G F R$ amplification, strong Int-Ab labeling and high levels of variant mRNAs. Our results indicated that the full-length EGFR and mutant EGFRvIII are not the sole EGFR isoform expressed in diffuse gliomas. This could explain discordant immunohistochemical results reported in the literature and may have therapeutic implications.
\end{abstract}

Correspondence to: Dr François Labrousse, Department of Pathology, Dupuytren University Hospital, 2 Avenue Martin Luther King, F-87042 Limoges, France

E-mail: labrousse@unilim.fr

Key words: gliomas, glioblastoma, epidermal growth factor receptor, EGFR isoforms, $E G F R$ mRNA variants

\section{Introduction}

According to the World Health Organization classification (WHO), adult diffuse gliomas include astrocytomas, glioblastomas, oligodendrogliomas and oligoastrocytomas (1). Despite therapeutic advances, these tumors remain incurable and the prognosis for patients afflicted with anaplastic tumors and glioblastomas is still very poor (2).

The epidermal growth factor receptor (EGFR) belongs to HER family, a group of four receptors. Many reports have shown that EGFR contribute to diffuse glioma oncogenesis (3-8). The most prevalent EGFR pathway modifications involved are $E G F R$ gene amplification and receptor overexpression, the latter of which remains controversial (9-15).

The EGFR gene is located in $7 \mathrm{p} 12$ and generates a first type of mRNA transcript, referred to as EGFR variant 1 (EGFRv1), which encodes the full-length receptor, known as isoform a, EGFR or HER1. Isoform a is a transmembrane protein with an intracellular tyrosine kinase domain. Ligand binding on the extracellular domain leads to stimulation of cellular proliferation and cell survival pathways. Glioblastomas harboring EGFR gene amplification frequently contain a genetic variant, EGFRvIII, which encodes a mutant receptor with an altered extracellular domain that renders it constitutively active (16-18).

In addition to variant v1, the $E G F R$ gene generates three other alternatively spliced transcripts, referred to as variants 2-4 (EGFRv2-v4). The corresponding mRNAs are shorter than the EGFRv1 transcript and, respectively, encode truncated forms of the receptor (isoforms b, c and d), which lack the cytoplasmic tyrosine kinase domain. Soluble isoforms have been reported (19-21). The role of these truncated EGFR isoforms remains poorly known. In vitro, they have been shown to decrease cellular proliferation $(22,23)$. The hypotheses for this cellular growth inhibition include the competitive binding of EGFR ligands by the truncated isoforms $(24,25)$ and formation of catalytically inactive heterodimers of different isoforms, which interfere with the formation of functional holoreceptor dimers. This consequently prevents intracellular kinase activity (26). To our knowledge, expressions of truncated EGFR isoforms and their transcripts have never been studied in gliomas.

To assess whether EGFR protein isoforms and their corresponding transcripts are expressed in diffuse gliomas, we 
A

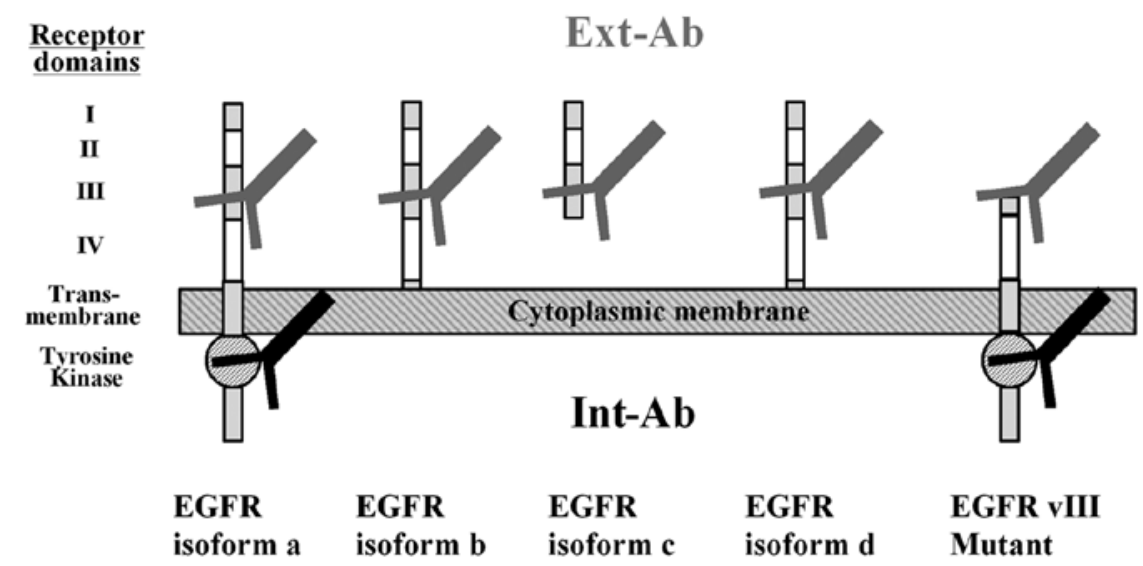

B

\begin{tabular}{|c|c|c|c|c|c|c|}
\hline \multirow{2}{*}{ Antibody } & \multicolumn{2}{|c|}{ Labeling location } & \multirow{2}{*}{ Target } & \multirow{2}{*}{ Nature and Host } & \multirow{2}{*}{ Dilution } & \multirow{2}{*}{ Manufacturer } \\
\hline & Non tumor cells & Tumor cells & & & & \\
\hline $\begin{array}{l}\text { Ext-Ab } \\
\text { Clone 3C6 }\end{array}$ & Membrane & $\begin{array}{l}\text { Membrane and/or } \\
\text { cytoplasm }\end{array}$ & $\begin{array}{c}\text { EGFR } \\
\text { extracellular domain }\end{array}$ & $\begin{array}{c}\text { Mouse } \\
\text { IgG monoclonal }\end{array}$ & Pure & $\begin{array}{l}\text { Ventana Medical } \\
\text { System, USA }\end{array}$ \\
\hline $\begin{array}{l}\text { Int-Ab } \\
\text { Clone EGFR. } 25\end{array}$ & Membrane & $\begin{array}{l}\text { Membrane and/or } \\
\text { cytoplasm }\end{array}$ & $\begin{array}{c}\text { EGFR } \\
\text { intracellular domain }\end{array}$ & $\begin{array}{c}\text { Mouse } \\
\text { IgG monoclonal }\end{array}$ & $1 / 500$ & $\begin{array}{c}\text { Novocastra } \\
\text { Laboratories, United } \\
\text { Kingdom }\end{array}$ \\
\hline
\end{tabular}

Figure 1. Characteristics of antibodies used in immunohistochemistry. (A), Ext-Ab (grey) and Int-Ab (black) targeting different domains of EGFR isoforms a, $\mathrm{b}, \mathrm{c}, \mathrm{d}$ and the EGFRvIII mutant; (B), Ext-Ab and Int-Ab characteristics.

performed an immunohistochemical analysis and determined the expression patterns of EGFRv1, -v2, -v3, -v4 and mutant EGFRvIII mRNAs. Results were analyzed with respect to the clinical data, patient outcome, histological tumor type and presence or absence of EGFR gene amplification.

\section{Patients and methods}

Patients and tissue samples. Tumors were obtained from 47 adult patients diagnosed with infiltrating glioma who were undergoing surgery at Limoges Dupuytren University Hospital between 1995 and 2011. Clinical and survival data were obtained by a retrospective query and all samples were used in accordance with French bioethics laws regarding patient information and consent. No patients received EGFR-targeted therapeutics. Tumor samples were fixed in $4 \%$ formalin at the time of resection. They were then embedded in paraffin and tumor sections were stained with hemalum phloxine saffron. Part of the surgical specimen was snap-frozen and conserved at $-80^{\circ} \mathrm{C}$. The histological type and grade of gliomas were determined according to the WHO classification (1). Non-tumor tissue was used as a control.

Immunohistochemistry. Sections $(5 \mu \mathrm{m})$ were cut from paraffinembedded tumors and stained with two different anti-EGFR antibodies (Fig. 1). One antibody targeted the extracellular domain (Ext-Ab) and the other intracellular domain (Int-Ab). Sample slides were processed automatically (BenchMark XT ICH/ISH, Ventana Medical Systems, Tucson, AZ, USA) according to protocols supplied by the manufacturers. EGFR staining was quantified according to a semiquantitative method proposed by Hirsch et al (27), as previously described (28). Staining was scored for labeling intensity (1, negative or trace; 2 , weak; 3 , moderate; 4 , intense), percentage of positive cells per slide (0\%-100\%) and for the Hirsch score resulting from multiplication of these two parameters (absolute values ranging from 0 to 400). For certain analyses, the level of expression in samples was scored as: negative or low, intermediate, and high, which corresponded to Hirsch values of 0-200, 201-300, and 301-400, respectively.

We also tested the following antibodies: Ki67 (clone MiB-1, DakoCytomation, Glostrup, Denmark; 1/200 $)$, p53 (Dako Cytomation; $1 / 50^{\mathrm{e}}$ ), Olig2 (Immuno-Biological Laboratories, Gunma, Japan; $1 / 200^{\mathrm{e}}$ ), and glial fibrillar acidic protein (Dako Cytomation; $1 / 1600^{\mathrm{e}}$ ). The percentages of cells labeled with these antibodies were determined by studying at least five hundred cells for each antibody in tumor areas of highest positivity.

Total RNA extraction. Tumor tissue $(30 \mathrm{mg})$ was incubated with $1 \mathrm{ml}$ Qiazol ${ }^{\circledR}$ solution (Qiagen, Courtaboeuf, France) and CK14 ceramic beads (Ozyme) and then pulverized two times for $40 \mathrm{sec}$ each at $6500 \mathrm{rpm}$ in a Precellys 24 homogenizer (Bertin Technologies). Homogenized tissues were then lysed and RNA purification was performed according to the manufacturer's protocol (RNeasy Lipid Tissue Mini kit, Qiagen). RNA concentration and purity was estimated by spectrophotometry (NanoDrop ND1000, Labtech, France). RNA quality was assessed by capillary electrophoresis (Bioanalyzer 2100, Agilent Technologies) and only RNA with an Integrity Number (R.I.N) $>6$ was used for analysis. 
Table I. Characteristics of the primer used for quantitative and qualitative RT-PCR.

\begin{tabular}{|c|c|c|c|c|c|}
\hline Target & Primer & Location & Sequence 5'-3' & Amplicon size (bp) & Primer temperature $\left({ }^{\circ} \mathrm{C}\right)$ \\
\hline EGFR variant 1 & $\begin{array}{l}\text { Forward } \\
\text { Reverse }\end{array}$ & $\begin{array}{l}\text { Exon } 29-30 \\
\text { Exon } 30\end{array}$ & $\begin{array}{l}\text { CTCCCAGTGCCTGAATACATA } \\
\text { GGCTGATTGTGATAGACAGGA }\end{array}$ & 83 & 58 \\
\hline EGFR variant 2 & $\begin{array}{l}\text { Forward } \\
\text { Reverse }\end{array}$ & $\begin{array}{l}\text { Exon } 15 \\
\text { Exon } 16\end{array}$ & $\begin{array}{l}\text { TGCACCTACGGGTCCTAAT } \\
\text { TGAAGCAAAGGGAGAAATTG }\end{array}$ & 97 & 58 \\
\hline EGFR variant 3 & $\begin{array}{l}\text { Forward } \\
\text { Reverse }\end{array}$ & $\begin{array}{l}\text { Exon } 10 \\
\text { Exon } 10 \text { bis }\end{array}$ & $\begin{array}{l}\text { AAGGAAATCACAGGTTTGAGC } \\
\text { TCCAAGGGAACAGGAAATATG }\end{array}$ & 99 & 58 \\
\hline EGFR variant 4 & $\begin{array}{l}\text { Forward } \\
\text { Reverse }\end{array}$ & $\begin{array}{l}\text { Exon } 15 \\
\text { Exon } 17\end{array}$ & $\begin{array}{l}\text { CTACGGGCCAGGAAATGAG } \\
\text { CGCTGCCATCATTACTTTGA }\end{array}$ & 86 & 62 \\
\hline HPRT & $\begin{array}{l}\text { Forward } \\
\text { Reverse }\end{array}$ & $\begin{array}{l}\text { Exon } 6 \\
\text { Exon } 7\end{array}$ & $\begin{array}{l}\text { CTTTCCTTGGTCAGGCAGTA } \\
\text { TGGCTTATATCCAACACTTCG }\end{array}$ & 90 & 58 \\
\hline EGFRvIII & $\begin{array}{l}\text { Forward } \\
\text { Reverse }\end{array}$ & $\begin{array}{l}\text { Exon } 1 \\
\text { Exon } 8\end{array}$ & $\begin{array}{l}\text { GCTCTGGAGGAAAAGAAAGGTAAT } \\
\text { TCСТCCATCTCATAGCTGTCG }\end{array}$ & 90 & 62 \\
\hline
\end{tabular}

Quantitative and qualitative RT-PCR. Complementary DNA (cDNA) was synthesized from $2 \mu \mathrm{g}$ of total RNA using the Transcriptor First Strand cDNA Synthesis ${ }^{\circledR}$ kit (Roche) and hexamer primers, according to the manufacturer's protocol. For PCR, primers were designed using Amplify 1.2 or Primer 3 (http://fokker.wi.mit.edu/primer3/input.html/) software and their specificity was determined by BLASTn in the NCBI database (http://www.ncbi.nlm.nih.gov/). Primer characteristics are listed in Table I. Amplicon size and specificity were initially determined by $4 \%$ NuSieve agarose gel electrophoresis. Quantitative PCR [EGFRv1, -v2, -v3, -v4 and hypoxanthine phosphoribosyl transferase (HPRT)] and qualitative PCR (EGFRvIII) were performed on a Rotor Gene thermocycler (Corbett Research) using the Light Cycler Fast Start DNA Master SYBR Green I kit (Roche). All targets were amplified twice in duplicate in the presence of $3 \mathrm{mM} \mathrm{MgCl}{ }_{2}$ and $0.5 \mu \mathrm{M}$ primers. Relative quantification of mRNA content was performed using the $\Delta \Delta \mathrm{Ct}$ method $\left[\left(\mathrm{Ct}_{\text {sample }}-\mathrm{Ct}_{\text {calibrator }}\right)_{\text {interest gene }}-\left(\mathrm{Ct}_{\text {sample }}-\mathrm{Ct}_{\text {calibrator }}\right)_{\text {reference gene }}\right]$, modified according to Pfaffl (29), with efficiency correction by Rotor Gene software. mRNA content was expressed in relative arbitrary units (R.A.U.).

Fluorescent in situ hybridization. EGFR gene amplification and $1 \mathrm{p} 36$ and $19 \mathrm{q} 13$ losses were analyzed by double fluorescent in situ hybridization with the 'LSI EGFR SpectrumOrange/ CEP 7 SpectrumGreen Probe', or with the 'LSI 1p36 spectrum orange/LSI 1q25 spectrum green probe' and the 'LSI 19q13 spectrum orange/LSI 19p13 spectrum green probe' (Abbott Molecular Inc., IL, USA) kits, respectively. They were investigated on consecutive paraffin sections from the same blocks used in immunohistochemical analyses. This technique was a modification of the method previously described (28): briefly, $4 \mu \mathrm{m}$ paraffin sections were incubated $16 \mathrm{~h}$ at $56^{\circ} \mathrm{C}$, submitted to deparaffinising, digested with pepsin (Abbott Molecular Inc.) at $37^{\circ} \mathrm{C}$ during $45 \mathrm{~min}$ and dehydrated in successive ethanol baths. Slides were incubated with $10 \mu \mathrm{l}$ of each probe for $5 \mathrm{~min}$ at $73^{\circ} \mathrm{C}$ to denature DNA and $16 \mathrm{~h}$ at $37^{\circ} \mathrm{C}$ to ensure hybridiza- tion. Sections were washed in $2 \mathrm{X}$ SSC/0.3\% NP40 solution, once for $1 \mathrm{~min}$ at room temperature, once for $2 \mathrm{~min}$ at $73^{\circ} \mathrm{C}$, and dehydrated in successive ethanol baths. Counterstaining and microscopic observation of EGFR amplification were performed as previously described (28). EGFR gene amplification was considered to have occurred if more than $10 \%$ of the cells analyzed produced a red (corresponding to the EGFRspecific probe) to green (centromeric region of chromosome 7) signal ratio $\geq 2$, as recommended previously (30,31). Eight sequential focus stacks with $0.3 \mu \mathrm{m}$ were acquired and then integrated into a single image in order to reduce thickness related artifacts. Preparations were considered as valid when more of $80 \%$ of the cells showed bright signals.

Statistical analyses. StatView ${ }^{\circledR} 5.0$ software (SAS Institute, Inc., Cary, NC, USA) was used for statistical analyses. Fisher's exact test was used to assess differences between nominal variables. Means were compared with the non-parametric Mann-Whitney test for pairs of variables and with the KruskallWallis tests for comparisons of more than two variables. Correlation Spearman test was used to compare quantitative variables. Overall survival (OS) and progression-free survival (PFS) were analyzed by Kaplan-Meier and median OS or PFS medians were compared with the non-parametric log-rank or Breslow tests. Results for which $\mathrm{p}<0.05$ were considered to be statistically significant.

\section{Results}

Patient and tumor characteristics. Patient characteristics are summarized in Table II. For the series, median follow-up was 23.3 (0.5-240) months. Ki67 labeling index, Olig2 and p53 protein expression, and presence or absence of a 1p36-19q13 loss were consistent with histological typing. Thus, oligodendrogliomas were characterized by a 1p36/19q13 deletion, stronger olig2 and weaker p53 expressions compared to other tumor types (Table III). 
Table II. Demographic, pathological and clinical features.

\begin{tabular}{|c|c|c|c|c|c|c|c|}
\hline & No. & Grade & $\begin{array}{c}\text { Sex } \\
\text { (male/female) }\end{array}$ & $\begin{array}{c}\text { Age } \\
\text { (median) }\end{array}$ & $\begin{array}{c}\text { Tumor status } \\
\text { (primary/recurrent) }\end{array}$ & $\begin{array}{l}\text { Radiotherapy } \\
\text { (yes/no) }\end{array}$ & $\begin{array}{c}\text { Chemotherapy } \\
\text { (yes/no) }\end{array}$ \\
\hline All & 47 & & $18 / 19$ & 50.6 & $36 / 11$ & $42 / 5$ & $37 / 10$ \\
\hline A & 3 & $1 \mathrm{II}, 2$ III & $1 / 2$ & 51.3 & 2/1 & $2 / 1$ & $2 / 1$ \\
\hline GBM & 21 & 21 IV & $10 / 11$ & 59.7 & $19 / 2$ & $20 / 1$ & $18 / 3$ \\
\hline $\mathrm{O}$ & 14 & 5 II, 9 III & $3 / 11$ & 48.1 & $10 / 4$ & $13 / 1$ & $13 / 1$ \\
\hline OA & 9 & 6 II, 3 III & $4 / 5$ & 43.2 & $5 / 4$ & $7 / 2$ & $4 / 5$ \\
\hline
\end{tabular}

A, astrocytoma; GBM, glioblastoma; O, oligodendroglioma; OA, oligoastrocytoma.

Table III. Molecular characterization of glioma histological types.

\begin{tabular}{|c|c|c|c|c|c|c|c|c|c|}
\hline & \multicolumn{2}{|c|}{$\operatorname{Ki} 67(n=45)$} & \multicolumn{2}{|c|}{$\mathrm{p} 53(\mathrm{n}=45)$} & \multicolumn{2}{|c|}{ Olig2 $(n=45)$} & \multicolumn{3}{|c|}{$1 \mathrm{p} 36-19 q 13$ loss $(n=46)$} \\
\hline & $\%$ Mean \pm SD & p-value & $\%$ Mean \pm SD & p-value & $\%$ Mean \pm SD & p-value & Yes & No & p-value \\
\hline All patients & $19 \pm 14$ & & $46.3 \pm 31.1$ & & $58.6 \pm 23.9$ & & 17 & 29 & \\
\hline \multicolumn{10}{|l|}{ Histological type } \\
\hline A & $13.7 \pm 10$ & 0.06 & $80 \pm 10$ & 0.0004 & $51.7 \pm 27.5$ & 0.04 & 0 & 3 & $<0.0001$ \\
\hline GBM & $26.9 \pm 13.5$ & & $49.7 \pm 28.3$ & & $48.7 \pm 25.8$ & & 2 & 18 & \\
\hline $\mathrm{O}$ & $14.8 \pm 19$ & & $20.6 \pm 18.4$ & & $71.8 \pm 18.3$ & & 14 & 0 & \\
\hline $\mathrm{OA}$ & $10.8 \pm 11.2$ & & $67.8 \pm 28.5$ & & $61.1 \pm 19$ & & 1 & 8 & \\
\hline
\end{tabular}

A, astrocytoma; GBM, glioblastoma; O, oligodendroglioma; OA, oligoastrocytoma.

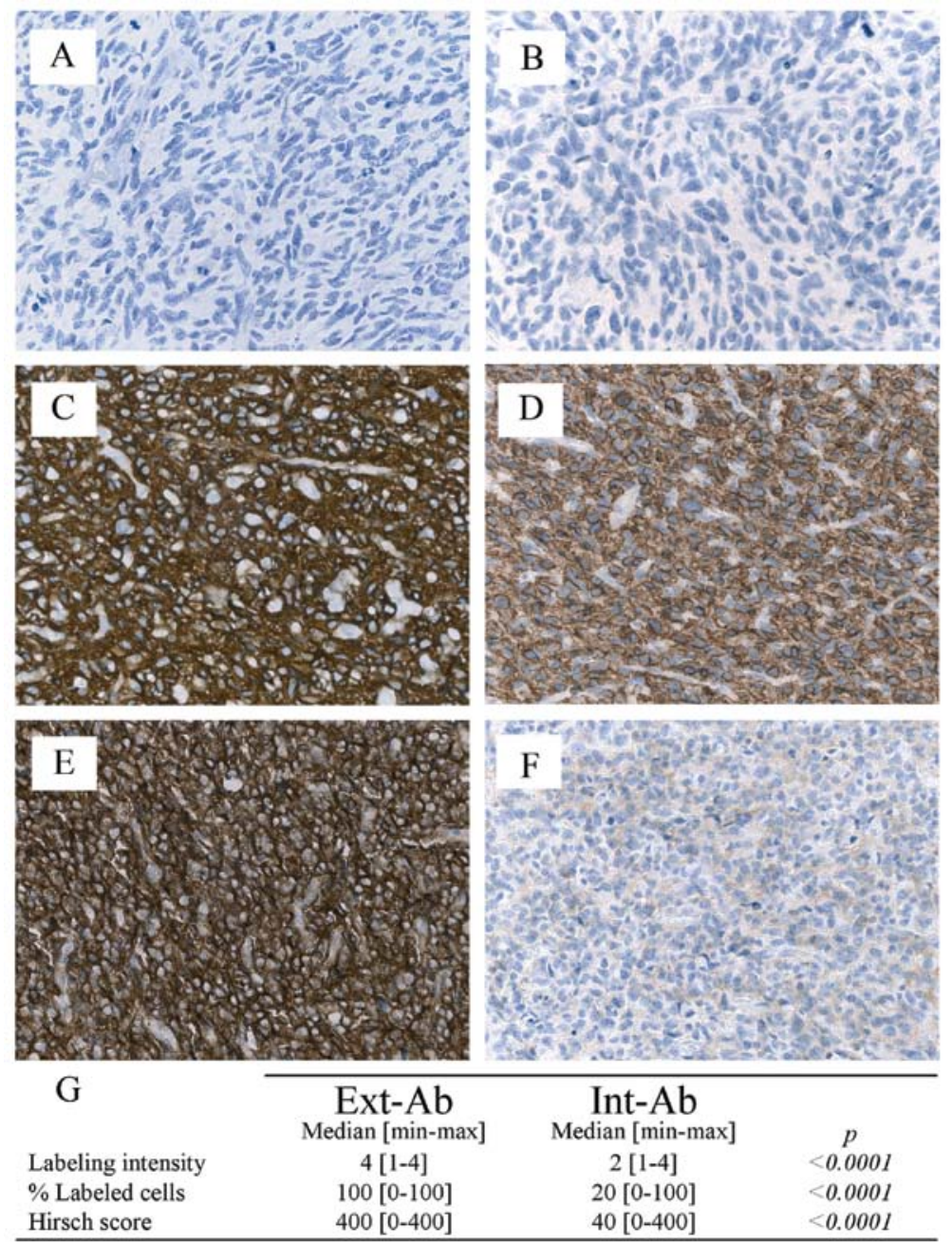

Figure 2. Immunohistochemical staining. Absence of labeling with both Ext-Ab (A) and Int-Ab (B) in a glioblastoma. Strong EGFR expression with both Ext-Ab (C) and Int-Ab (D) in a glioblastoma. Discordant staining: strong with the Ext-Ab (E) and very weak with the Int-Ab (F) in a grade III oligodendroglioma. (G), table of statistical analysis. 
Immunohistochemical detection of EGFR isoforms and EGFRvIII mutant. The percentage of gliomas stained by Ext-Ab was $98 \%$ (44/45), whereas only $78 \%$ (35/45) of the gliomas were stained by Int-Ab. The Ext-Ab and Int- $\mathrm{Ab}$ antibodies generated very different staining patterns in the gliomas (Fig. 2A-F). Glioma staining by Int-Ab was significantly lower than that of Ext- $\mathrm{Ab}$ in terms of intensity, percentage of positive cells and Hirsch score ( $\mathrm{p}<0.0001$; Fig. 2G).

Neither antibody detected any significant differences in EGFR staining with respect to patient sex or age (data not shown). Staining intensities, percentages of labeled cells and Hirsch scores obtained with Ext-Ab did not significantly differ according to histological types. In contrast, Int-Ab scores were significantly higher in glioblastomas, astrocytomas or oligodendrogliomas compared to oligoastrocytomas (Table IV). In non-tumor tissue, we found no or very weak EGFR expression whatever the antibody used.

Quantitation of EGFR variants 1, 2, 3, 4 and EGFRvIII mRNAs. EGFR mRNA levels varied widely among the tumor samples. Median R.A.U. values were 7.3 (0.4-390.2) for EGFRv1+vIII mRNA, 0.02 (0-0.5) for EGFRv2 mRNA, 6.2 (0.1-1396.8) for EGFRv3 mRNA and 94.6 (2.1-4445.2) for EGFRv4 mRNA. Straight correlations were found for all comparisons between EGFRv1+vIII, -v2, -v3 and -v4 mRNA levels ( $<<0.0001$ for all, Fig. 3). EGFRvIII mutant expression was qualitatively detected in 26\% (12/47) of the gliomas. In non-tumor tissue mRNA variant were very weakly expressed with 0.7 R.A.U. for EGFRv1+vIII and EGFRv3, 6.6 R.A.U. for EGFRv4 and no EGFRvIII and EGFRv2 expression.

Association of EGFR variant and EGFRvIII mRNA expression with other parameters. EGFRv1+vIII, -v2, -v3, and -v4 mRNA levels were not influenced by patient sex and age (data not shown). EGFRv1+vIII, -v3 and -v4 mRNA levels were higher in glioblastomas than in other tumor types when mean values were taken as a cut-off ( $\mathrm{p}=0.04,0.01$ and 0.002 , respectively) (Fig. 4). EGFRvIII mRNA was significantly associated with histological type, it was found in one astrocytoma, ten glioblastomas and one oligoastrocytoma, but in none oligodendroglioma ( $\mathrm{p}=0.01$, data not shown). We also observed that EGFRv1+vIII mRNA levels more straightly correlated with Int-Ab staining than with Ext-Ab staining (Fig. 5).

EGFR gene amplification in gliomas. We detected EGFR gene amplification in 8 out of the 20 glioblastomas, but not in the other glioma types $(\mathrm{p}=0.007$, Table V). Glioblastomas with $E G F R$ gene amplification expressed significantly stronger EGFRv1, -v2, -v3 and -v4 mRNA levels than gliomas with no EGFR amplification (Table V). The presence of mutant EGFRvIII mRNA was significantly associated with EGFR amplification $(\mathrm{p}<0.0001)$.

Weak Ext-Ab staining was more closely associated with the absence of $E G F R$ gene amplification than with its presence $(\mathrm{p}=0.09)$, whereas strong Int-Ab staining was significantly associated with gene amplification ( $p=0.01$; Fig. 6 ).

Prognostic values. PFS and OS were significantly shorter for patients diagnosed with glioblastoma and astrocytoma than for those with oligodendroglioma and oligoastrocytoma $(p<0.0001$

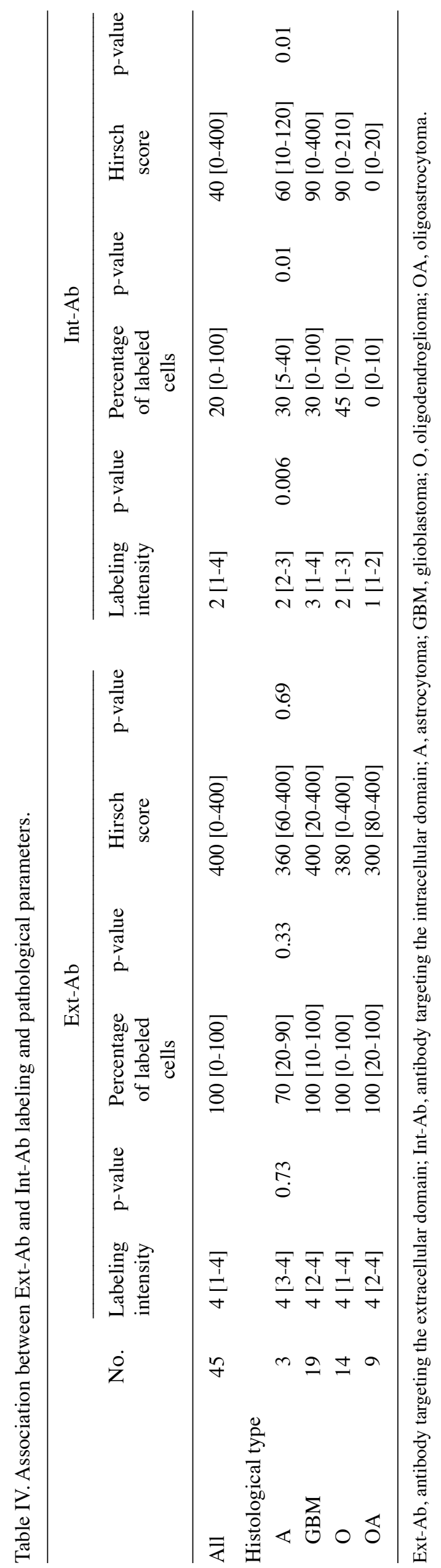



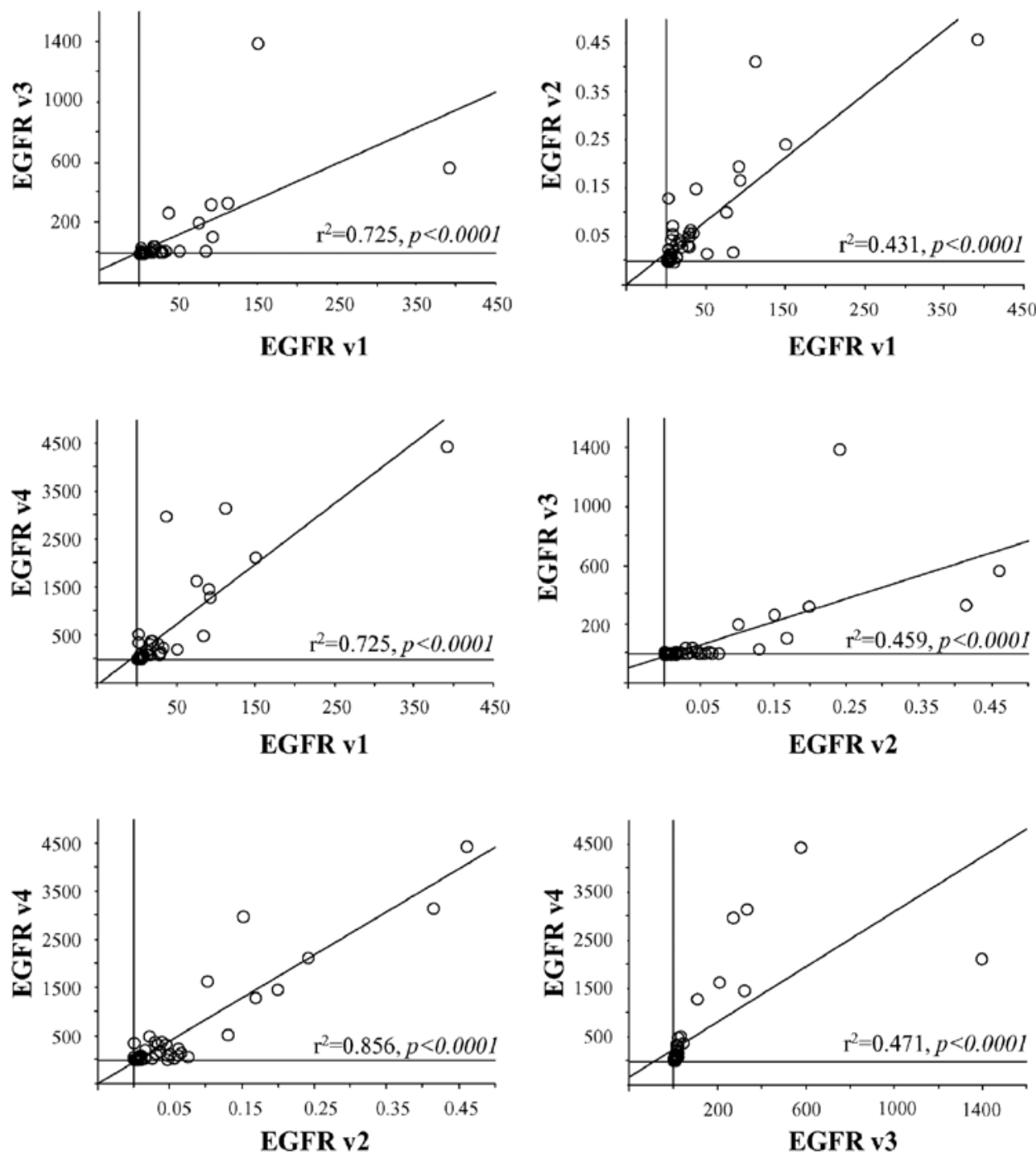

Figure 3. Correlation for EGFRv1+vIII, -v2, -v3 and -v4 mRNA levels.

for both) (Table VI, Fig. 7A). OS and PFS were better for patients with tumors showing a 1p36-19q13 loss and an absence of EGFR amplification (Table VI).

No/intermediate or strong tumor labeling with EGFR Ext-Ab did not influence OS and PFS times whereas no/intermediate labeling with EGFR Int-Ab was associated with longer OS and PFS (Table VI). In addition, PFS and OS were longer when gliomas expressed weak EGFRv1+vIII, -v2, v3, or -v4 mRNA levels and showed no mutant EGFRvIII mRNA expression (Table VI, Fig. 7B-F).

In glioblastomas (data not shown), PFS was significantly better for patients with no EGFR amplification (5.4 vs. 8.4 months, $\mathrm{p}=0.01$ ), no expression of EGFRvIII mutant mRNA (3.7 vs. 8.4 months, $\mathrm{p}=0.04$ ), or weak EGFRv2 (3.3 vs. 5.6 months, $\mathrm{p}=0.04)$ or $-\mathrm{v} 4$ mRNA levels (8.4 vs. 4.7 months, $\mathrm{p}=0.05)$. OS did not change according to these parameters.

\section{Discussion}

Based on the present results, we report that diffuse gliomas expressed truncated EGFR protein isoforms, based on: i) immunohistochemical data and ii) EGFRv1, -v2, -v3, -v4 variants and EGFRvIII mutant mRNA detection.
Immunohistochemical results varied according to the antibody used and favored the hypothesis of an expression of the truncated isoforms. The stronger EGFR staining obtained with Ext-Ab reflected their expression since, in addition to functional EGFR and the EGFRvIII mutant targeted by both antibodies, Ext-Ab also recognized the truncated EGFR isoforms $b, c$, and $\mathrm{d}$ whereas Int-Ab did not. The detection of truncated isoforms, depending on the antibody used, could explain some of the discrepancies found in literature regarding EGFR expression in gliomas (9-15). In our series, glioblastomas and oligodendrogliomas were strongly labeled by both Ext-Ab and Int-Ab, whereas oligoastrocytomas were moderately or strongly labeled by Ext-Ab but weakly by Int-Ab. Thus, in combination with other markers such as Olig2, p53 or 1p19q deletion, the study of EGFR expression might be useful to further characterize the diffuse gliomas (32-36).

The transcriptomic analysis showed that alternatively spliced EGFRv2, -v3 and -v4 transcript variants, encoding EGFR isoforms b, c and d, respectively, were expressed in addition to the EGFRv1 and EGFRvIII mutant mRNAs. In accordance with immunohistochemistry, detection of EGFRv1+vIII mRNA associated more closely with Int-Ab staining than with Ext-Ab staining. However, we also found an association between 

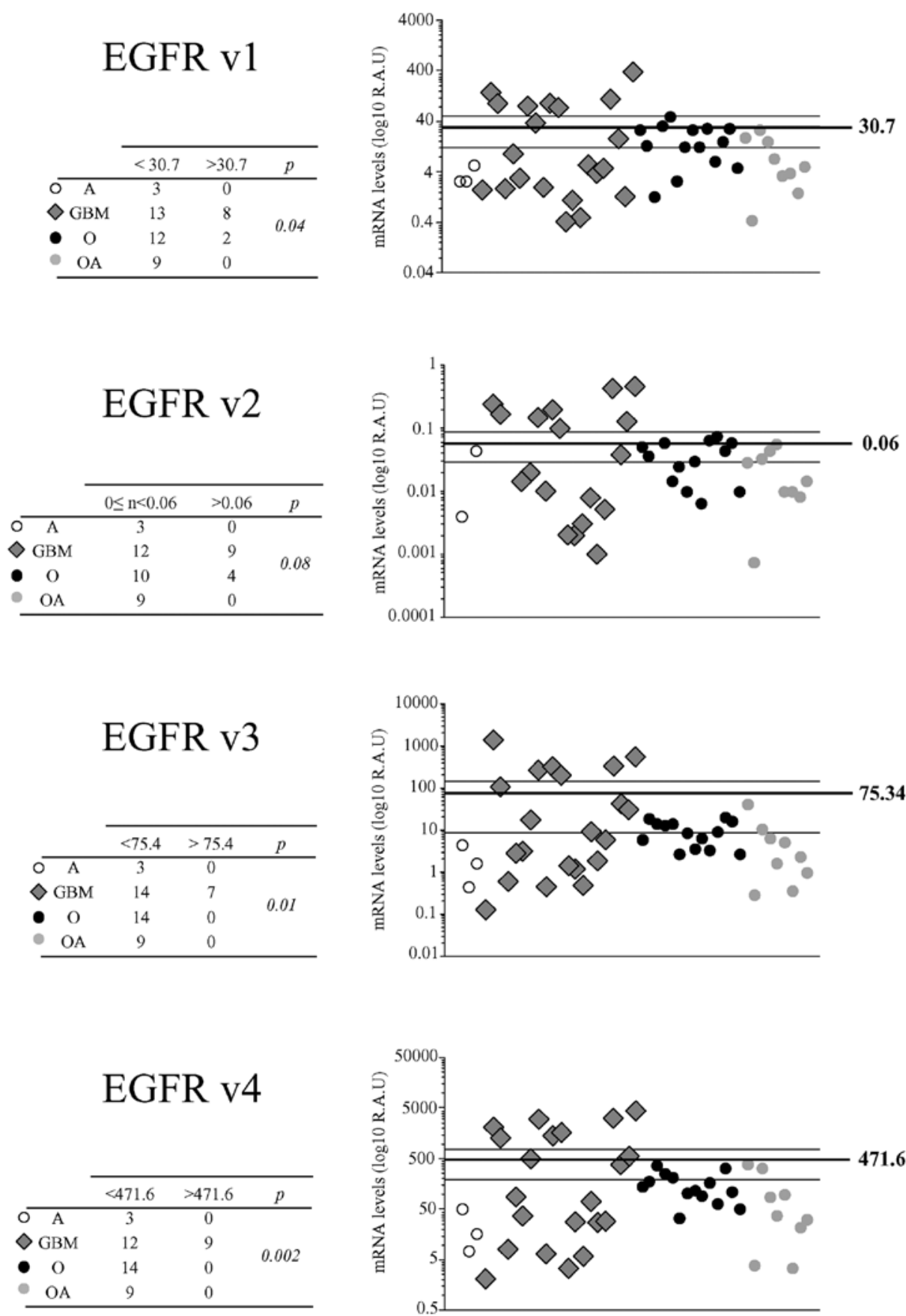

Figure 4. Relation between EGFR variant mRNA levels and histological types. EGFRv1+vIII, -v2, -v3 and -v4 mRNA levels were expressed in Log10 relative arbitrary unit ( $\log 10$ R.A.U). Mean value was taken as a cut-off to determine the number of tumors under $(<$ mean) and above $(>$ mean) it.

A

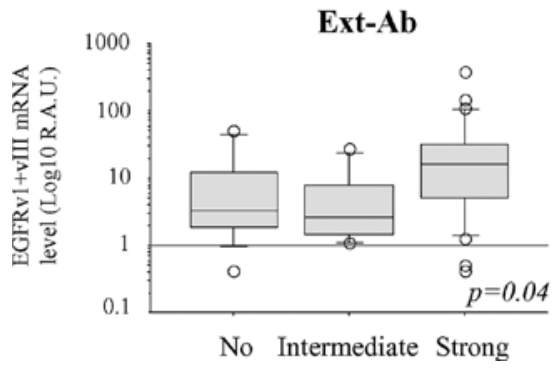

B

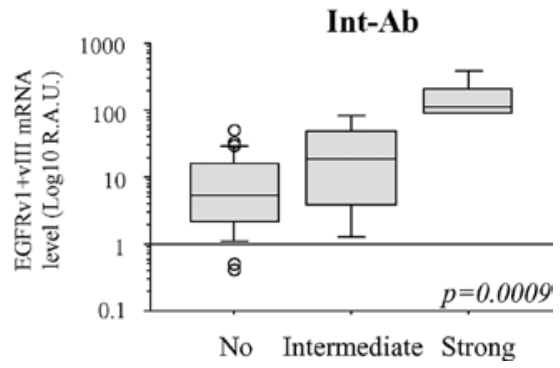

Figure 5. Relation between EGFRv1+vIII mRNA levels and immunohistochemical data. Ext-Ab (A) and Int-Ab (B) labeling were expressed as no vs. intermediate vs. strong Hirsch score. 
Table V. EGFR amplification.

\begin{tabular}{|c|c|c|c|}
\hline & \multicolumn{3}{|c|}{$E G F R$ amplification } \\
\hline & No. & Yes & $\mathrm{p}$-value \\
\hline \multicolumn{4}{|c|}{ Histological type } \\
\hline A & 3 & 0 & 0.007 \\
\hline GBM & 12 & 8 & \\
\hline $\mathrm{O}$ & 13 & 0 & \\
\hline $\mathrm{OA}$ & 9 & 0 & \\
\hline \multicolumn{4}{|c|}{ EGFRv1+vIII mRNA } \\
\hline$<$ mean & 34 & 2 & 0.0001 \\
\hline$>$ mean & 3 & 6 & \\
\hline \multicolumn{4}{|c|}{ EGFRv2 mRNA } \\
\hline$<$ mean & 32 & 2 & 0.001 \\
\hline$>$ mean & 5 & 6 & \\
\hline \multicolumn{4}{|c|}{ EGFRv3 mRNA } \\
\hline$<$ mean & 36 & 1 & $<0.0001$ \\
\hline$>$ mean & 3 & 5 & \\
\hline \multicolumn{4}{|c|}{ EGFRv4 mRNA } \\
\hline$<$ mean & 36 & 1 & $<0.0001$ \\
\hline$>$ mean & 1 & 7 & \\
\hline \multicolumn{4}{|c|}{ EGFRvIII mRNA } \\
\hline Present & 4 & 7 & $<0.0001$ \\
\hline Absent & 33 & 1 & \\
\hline
\end{tabular}

A, astrocytoma; GBM, glioblastoma; O, oligodendroglioma; OA, oligoastrocytoma.

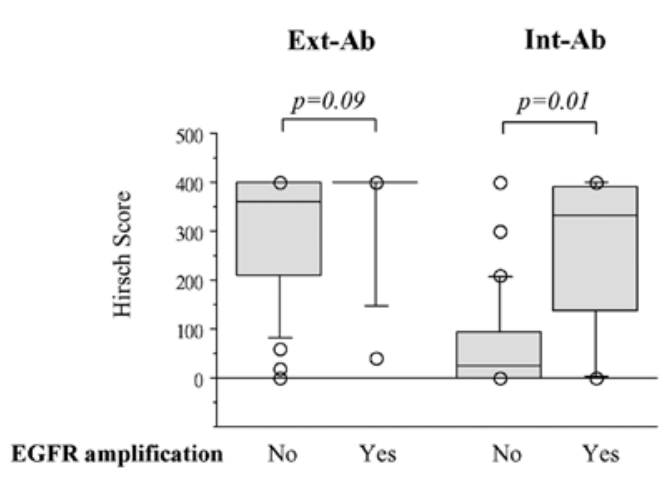

Figure 6. Association between EGFR gene amplification and immunohistochemical staining. Ext-Ab (A) and Int-Ab (B) staining expressed as Hirsch scores was compared in tumors exhibiting or lacking EGFR gene amplification.

Int-Ab staining and EGFRv2, -v3 and -v4 transcript expressions, although Int- $\mathrm{Ab}$ did not detect the isoform they encode. This association is probably the consequence of the strong link existing between the expressions of each EGFR transcript (Fig. 3). Nevertheless, alternatively spliced EGFR transcript variants and EGFRvIII mRNA were produced at different levels according to the histological type of glioma. The glioblastomas
Table VI. PFS and OS according to histological and molecular parameters.

\begin{tabular}{|c|c|c|c|c|}
\hline & \multicolumn{2}{|c|}{ PFS } & \multicolumn{2}{|c|}{ OS } \\
\hline & $\begin{array}{l}\text { Median } \\
\text { (months) }\end{array}$ & p-value & $\begin{array}{l}\text { Median } \\
\text { (months) }\end{array}$ & $\mathrm{p}$-value \\
\hline \multicolumn{5}{|l|}{ Histological types } \\
\hline A & 16.4 & $<0.0001$ & 34.9 & $<0.0001$ \\
\hline GBM & 5.4 & & 10.9 & \\
\hline $\mathrm{O}$ & 45.1 & & 93.3 & \\
\hline $\mathrm{OA}$ & 41 & & $\mathrm{nr}$ & \\
\hline \multicolumn{5}{|l|}{ EGFR amplification } \\
\hline Yes & 4.7 & $<0.0001$ & 8.8 & 0.0003 \\
\hline No & 21.6 & & 93.3 & \\
\hline \multicolumn{5}{|l|}{ 1p36-19q13 loss } \\
\hline Yes & 21.9 & 0.04 & 93.3 & 0.09 \\
\hline No & 16.4 & & 24 & \\
\hline \multicolumn{5}{|l|}{ Ext-Ab } \\
\hline No/intermediate & 22.7 & 0.25 & 52.8 & 0.7 \\
\hline Strong & 16.4 & & 93.3 & \\
\hline \multicolumn{5}{|l|}{ Int-Ab } \\
\hline No/intermediate & 21.4 & 0.006 & 93.3 & 0.07 \\
\hline Strong & 4.7 & & 21.6 & \\
\hline \multicolumn{5}{|l|}{ EGFRv1 mRNA } \\
\hline Weak & 21 & $0.02^{\mathrm{a}}$ & 93.3 & 0.1 \\
\hline Strong & 5.4 & & 21.6 & \\
\hline \multicolumn{5}{|l|}{ EGFRv2 mRNA } \\
\hline Weak & 21.4 & $0.01^{\mathrm{a}}$ & 52.8 & 0.007 \\
\hline Strong & 9 & & 15.1 & \\
\hline \multicolumn{5}{|l|}{ EGFRv3 mRNA } \\
\hline Weak & 21 & 0.0007 & 93.3 & 0.004 \\
\hline Strong & 4.7 & & 10.9 & \\
\hline \multicolumn{5}{|l|}{ EGFRv4 mRNA } \\
\hline Weak & 21.4 & $<0.0001$ & 93.3 & 0.0006 \\
\hline Strong & 4.7 & & 10.9 & \\
\hline \multicolumn{5}{|l|}{ EGFRvIII mRNA } \\
\hline No & 21.4 & 0.0007 & 52.8 & 0.03 \\
\hline Yes & 4.7 & & 10.9 & \\
\hline
\end{tabular}

${ }^{a}$ The difference was not significant using log-rank test but was significant with Breslow-Gehan-Wilcoxon test. OS, overall survival; PFS, progression-free survival; Nr, not reached; A, astrocytoma; GBM, glioblastoma; O, oligodendroglioma; OA, oligoastrocytoma.

had a peculiar profile. They expressed the highest levels of EGFRv3 and -v4 mRNA transcripts and, in addition, EGFRvIII mRNA expression was related to this tumor type.

EGFR gene amplification was detected in eight glioblastomas. As previously reported (28), weak Ext-Ab staining was 

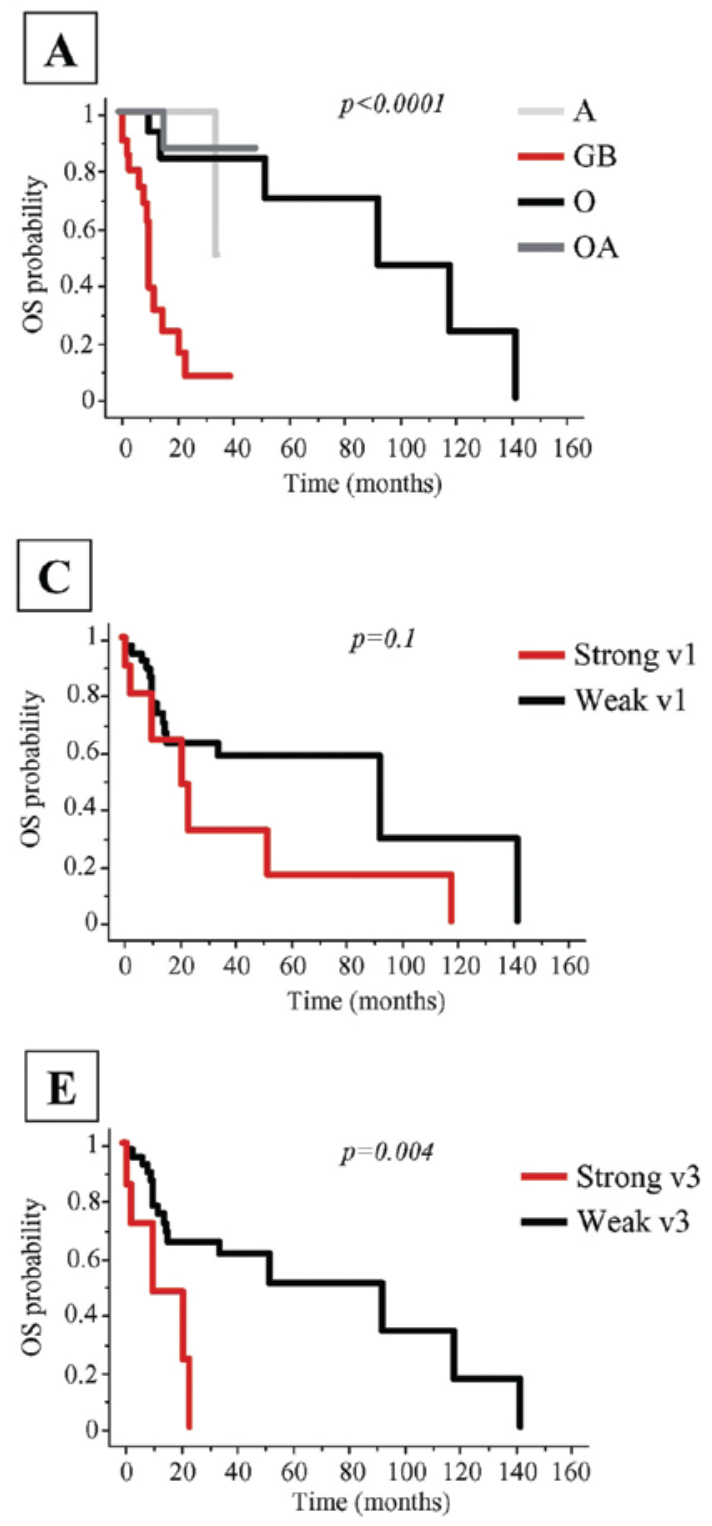
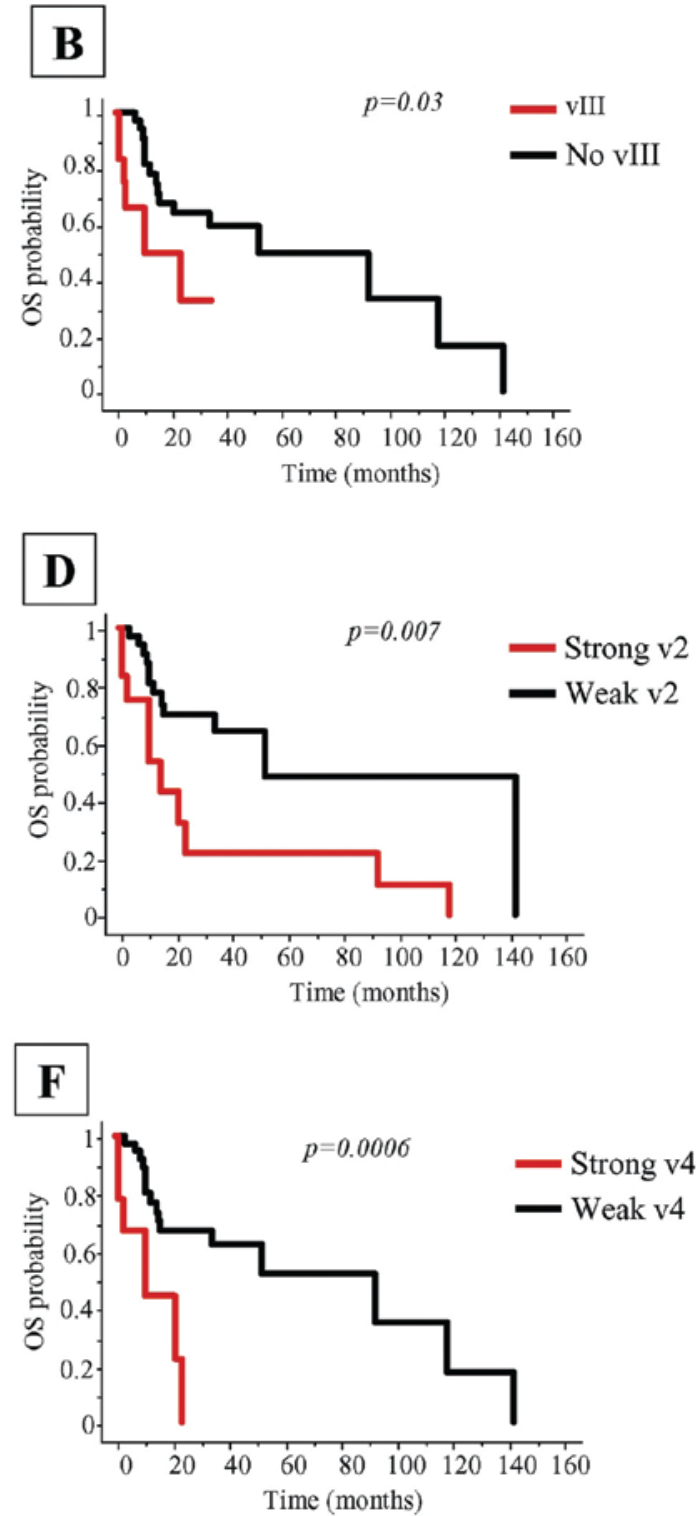

Figure 7. Patient overall survival (OS). Differences in OS according to histological types (A), mutant EGFRvIII expression (B), EGFRv1+vIII (C), -v2 (D), -v3 (E) and -v4 (F) mRNA levels were assessed by log-rank test.

associated with the lack of EGFR amplification. In contrast, Int-Ab staining intensity directly correlated with $E G F R$ gene amplification, as already shown (37). This suggests that EGFR gene amplification is tightly associated with high expression of EGFR receptor isoforms that contain the intracellular tyrosine kinase domain, i.e., EGFR isoform a and the EGFRvIII mutant. Regarding the relationships with the prognosis in our series, the histological type (astrocytoma and glioblastoma), a strong staining with Int-Ab and the presence of EGFR amplification and of mutant vIII were associated with shorter PFS and OS times. High levels of EGFRv2, -v3 and -v4 transcript expression were also related to a shortened OS and PFS.

Our data tend to indicate that the role of EGFR pathway in glioblastoma oncogenesis is more complex than expected. In our series, in addition to the known molecular alterations i.e., EGFR gene amplification and expression of vIII mutant, we observed a strong staining with Int-Ab and high levels of EGFR
mRNA variants. Actually, the functional roles of the truncated EGFR isoforms are poorly known, particularly in vivo. In vitro, it has been described that soluble isoforms may regulate EGFR signaling in normal and tumor cells $(26,38)$. Paradoxically, these isoforms have been shown to decrease cellular proliferation $(22,23)$. The known mechanisms responsible for growth inhibition include competitive binding of ligands to soluble isoforms and formation of inactive heterodimers which inhibit the formation of holoreceptor dimers and/or intracellular kinase activity (24-26).

The presence of truncated EGFR isoforms in adult infiltrating gliomas must be considered in therapeutic management. The interactions between truncated EGFR isoforms and EGFRtargeted therapeutics are not well understood. The presence of non-functional receptors could contribute to the failure of therapeutics which target the EGFR extracellular domain (39). Conversely, it has been reported that the presence of truncated 
EGFR isoforms may be predictive of the therapeutic response to gefitinib in endometrious adenocarcinomas (40). Lafky and coworkers speculated that the soluble vascular endothelial growth factor receptor (sVEGFR) represents a paradigm for understanding the function and potential application of EGFR isoforms as novel therapeutic molecules (41). Soluble VEGFR isoforms have been presented as effective therapeutic molecules (42) and a similar application for certain EGFR truncated isoforms may be possible.

To our knowledge, this is the first report that gliomas express EGFR transcripts other than EGFRv1 mRNA, which encodes the full-length and functional EGFR isoform a. The role of EGFR isoforms in glioma pathogenesis remains to be clarified, but their expression makes them potential targets of future diagnostic and therapeutic strategies.

\section{Acknowledgments}

This work was supported by grants from the 'Comité Départemental de la Ligue contre le Cancer de la Corrèze'. We thank Mrs. Marion Porcheron for technical assistance, the 'Tumorothèque du Limousin' for providing all tissue samples and the 'Plateforme d'Oncologie Moléculaire' of the Limoges Dupuytren University Hospital.

\section{References}

1. Louis DN, Ohgaki H, Wiestler OD, Cavenee WK, Burger PC, Jouvet A, Scheithauer BW and Kleihues P: The 2007 WHO classification of tumours of the central nervous system. Acta Neuropathol 114: 97-109, 2007.

2. Krex D, Klink B, Hartmann C, von Deimling A, Pietsch T, Simon M, Sabel M, Steinbach JP, Heese O, Reifenberger G, Weller M and Schackert G: Long-term survival with glioblastoma multiforme. Brain 130: 2596-2606, 2007.

3. Andersson U, Guo D, Malmer B, Bergenheim AT, Brannstrom T, Hedman $\mathrm{H}$ and Henriksson R: Epidermal growth factor receptor family (EGFR, ErbB2-4) in gliomas and meningiomas. Acta Neuropathol 108: 135-142, 2004.

4. Bredel M, Pollack IF, Hamilton RL and James CD: Epidermal growth factor receptor expression and gene amplification in high-grade non-brainstem gliomas of childhood. Clin Cancer Res 5: 1786-1792, 1999.

5. McLendon RE, Turner K, Perkinson K and Rich J: Second messenger systems in human gliomas. Arch Pathol Lab Med 131: 1585-1590, 2007

6. Potti A, Forseen SE, Koka VK, Pervez H, Koch M, Fraiman G, Mehdi SA and Levitt R: Determination of HER-2/neu overexpression and clinical predictors of survival in a cohort of 347 patients with primary malignant brain tumors. Cancer Invest 22: 537-544, 2004

7. Schlegel J, Stumm G, Brandle K, Merdes A, Mechtersheimer G, Hynes NE and Kiessling M: Amplification and differential expression of members of the erbB-gene family in human glioblastoma. J Neurooncol 22: 201-207, 1994.

8. Tabori U, Rienstein S, Dromi Y, Leider-Trejo L, Constantini S, Burstein Y, Dvir R, Amariglio N, Toren A, Rechavi G, Izraeli S and Aviram A: Epidermal growth factor receptor gene amplification and expression in disseminated pediatric low-grade gliomas. J Neurosurg 103: 357-361, 2005.

9. Gil-Benso R, Lopez-Gines C, Benito R, Lopez-Guerrero JA, Callaghan RC, Pellin A, Roldan P and Cerda-Nicolas M: Concurrent EGFR amplification and TP-53 mutation in glioblastomas. Clin Neuropathol 26: 224-231, 2007.

10. Nakamura JL: The epidermal growth factor receptor in malignant gliomas: pathogenesis and therapeutic implications. Expert Opin Ther Targets 11: 463-472, 2007.

11. Okada Y, Ohno C, Ueki K, Ogino M, Kawamoto S and Kim P. Comparison of numerical change of epidermal growth factor receptor gene among pre- and postradiation glioma, and gliosis, and its clinical use. Brain Tumor Pathol 24: 15-18, 2007.
12. Schober R, Bilzer T, Waha A, et al: The epidermal growth factor receptor in glioblastoma: genomic amplification, protein expression, and patient survival data in a therapeutic trial. Clin Neuropathol 14: 169-174, 1995

13. Shinojima N, Tada K, Shiraishi S, Kamiryo T, Kochi M, Nakamura H, Makino K, Saya H, Hirano H, Kuratsu J, Oka K, Ishimaru Y and Ushio Y: Prognostic value of epidermal growth factor receptor in patients with glioblastoma multiforme. Cancer Res 63: 6962-6970, 2003

14. Torp SH, Helseth E, Dalen A and Unsgaard G: Epidermal growth factor receptor expression in human gliomas. Cancer Immunol Immunother 33: 61-64, 1991.

15. Torp SH, Helseth E, Ryan L, Stolan S, Dalen A and Unsgaard G: Amplification of the epidermal growth factor receptor gene in human gliomas. Anticancer Res 11: 2095-2098, 1991.

16. Gan HK, Kaye AH and Luwor RB: The EGFRvIII variant in glioblastoma multiforme. J Clin Neurosci 16: 748-754, 2009.

17. Lal A, Glazer CA, Martinson HM, Friedman HS, Archer GE, Sampson JH and Riggins GJ: Mutant epidermal growth factor receptor up-regulates molecular effectors of tumor invasion. Cancer Res 62: 3335-3339, 2002.

18. Sampson JH, Heimberger AB, Archer GE, Aldape KD, Friedman AH, Friedman HS, Gilbert MR, Herndon JE II, McLendon RE, Mitchell DA, Reardon DA, Sawaya R, Schmittling RJ, Shi W, Vredenburgh JJ and Bigner DD: Immunologic escape after prolonged progression-free survival with epidermal growth factor receptor variant III peptide vaccination in patients with newly diagnosed glioblastoma. J Clin Oncol 28: 4722-4729, 2010

19. Maihle NJ, Baron AT, Barrette BA, Boardman $\mathrm{CH}$, Christensen TA, Cora EM, Faupel-Badger JM, Greenwood T, Juneja SC, Lafky JM, Lee H, Reiter JL and Podratz KC: EGF/ ErbB receptor family in ovarian cancer. Cancer Treat Res 107: 247-258, 2002.

20. Reiter JL and Maihle NJ: Characterization and expression of novel $60-\mathrm{kDa}$ and 110-kDa EGFR isoforms in human placenta. Ann NY Acad Sci 995: 39-47, 2003.

21. Reiter JL, Threadgill DW, Eley GD, Strunk KE, Danielsen AJ, Sinclair CS, Pearsall RS, Green PJ, Yee D, Lampland AL, Balasubramaniam S, Crossley TD, Magnuson TR, James CD and Maihle NJ: Comparative genomic sequence analysis and isolation of human and mouse alternative EGFR transcripts encoding truncated receptor isoforms. Genomics 71: 1-20, 2001.

22. Flickinger TW, Maihle NJ and Kung HJ: An alternatively processed mRNA from the avian c-erbB gene encodes a soluble, truncated form of the receptor that can block ligand-dependent transformation. Mol Cell Biol 12: 883-893, 1992.

23. Weber W, Gill GN and Spiess J: Production of an epidermal growth factor receptor-related protein. Science 224: 294-297, 1984.

24. Cadena DL and Gill GN: Expression and purification of the epidermal growth factor receptor extracellular domain utilizing a polycistronic expression system. Protein Expr Purif 4: 177-186, 1993.

25. Greenfield C, Hiles I, Waterfield MD, Federwisch M, Wollmer A, Blundell TL and McDonald N: Epidermal growth factor binding induces a conformational change in the external domain of its receptor. EMBO J 8: 4115-4123, 1989.

26. Basu A, Raghunath M, Bishayee S and Das M: Inhibition of tyrosine kinase activity of the epidermal growth factor (EGF) receptor by a truncated receptor form that binds to EGF: role for interreceptor interaction in kinase regulation. Mol Cell Biol 9: 671-677, 1989

27. Hirsch FR, Varella-Garcia M, Bunn PA Jr, Di Maria MV, Veve R, Bremmes RM, Baron AE, Zeng C and Franklin WA: Epidermal growth factor receptor in non-small-cell lung carcinomas: correlation between gene copy number and protein expression and impact on prognosis. J Clin Oncol 21: 3798-3807, 2003.

28. Guillaudeau A, Durand K, Pommepuy I, Robert S, Chaunavel A, Lacorre S, De Armas R, Bourtoumieux S, El Demery M, Moreau JJ and Labrousse F: Determination of EGFR status in gliomas: usefulness of immunohistochemistry and fluorescent in situ hybridization. Appl Immunohistochem Mol Morphol 17: 220-226, 2009.

29. Pfaffl MW: A new mathematical model for relative quantification in real-time RT-PCR. Nucleic Acids Res 29: e45, 2001.

30. Korshunov A, Sycheva R and Golanov A: Molecular stratification of diagnostically challenging high-grade gliomas composed of small cells: the utility of fluorescence in situ hybridization. Clin Cancer Res 10: 7820-7826, 2004 
31. Marks RA,Zhang S, Montironi R, McCarthy RP, MacLennan GT, Lopez-Beltran A, Jiang Z, Zhou H, Zheng S, Davidson DD, Baldridge LA and Cheng L: Epidermal growth factor receptor (EGFR) expression in prostatic adenocarcinoma after hormonal therapy: a fluorescence in situ hybridization and immunohistochemical analysis. Prostate 68: 919-923, 2008.

32. Durand K, Guillaudeau A,Pommepuy I, Mesturoux L, Chaunavel A, Gadeaud E, Porcheron M, Moreau JJ and Labrousse F: Alphainternexin expression in gliomas: relationship with histological type and 1p, 19q, 10p and 10q status. J Clin Pathol 64: 793-801, 2011.

33. Durand KS, Guillaudeau A, Weinbreck N, De Armas R, Robert S, Chaunavel A, Pommepuy I, Bourthoumieu S, Caire F, Sturtz FG and Labrousse FJ: 1p19q LOH patterns and expression of p53 and Olig2 in gliomas: relation with histological types and prognosis. Mod Pathol 23: 619-628, 2010.

34. Hirose T, Ishizawa K and Shimada S: Utility of in situ demonstration of $1 \mathrm{p}$ loss and $\mathrm{p} 53$ overexpression in pathologic diagnosis of oligodendroglial tumors. Neuropathology 30: 586-596, 2010.

35. Ligon KL, Alberta JA, Kho AT, Weiss J, Kwaan MR, Nutt CL, Louis DN, Stiles CD and Rowitch DH: The oligodendroglial lineage marker OLIG2 is universally expressed in diffuse gliomas. J Neuropathol Exp Neurol 63: 499-509, 2004.

36. Okada M, Yano H, Hirose Y, Nakayama N, Ohe N, Shinoda J and Iwama T: Olig2 is useful in the differential diagnosis of oligodendrogliomas and extraventricular neurocytomas. Brain Tumor Pathol 28: 157-161, 2011.
37. Coulibaly B, Nanni I, Quilichini B, Gaudart J, Metellus P, Fina F, Boucard C, Chinot O, Ouafik L and Figarella-Branger D: Epidermal growth factor receptor in glioblastomas: correlation between gene copy number and protein expression. Hum Pathol 41: 815-823, 2010 .

38. Ilekis JV, Stark BC and Scoccia B: Possible role of variant RNA transcripts in the regulation of epidermal growth factor receptor expression in human placenta. Mol Reprod Dev 41: 149-156, 1995.

39. Voelzke WR, Petty WJ and Lesser GJ: Targeting the epidermal growth factor receptor in high-grade astrocytomas. Curr Treat Options Oncol 9: 23-31, 2008.

40. Albitar L, Pickett G, Morgan M, Wilken JA, Maihle NJ and Leslie KK: EGFR isoforms and gene regulation in human endometrial cancer cells. Mol Cancer 9: 166, 2010.

41. Lafky JM, Wilken JA, Baron AT and Maihle NJ: Clinical implications of the ErbB/epidermal growth factor (EGF) receptor family and its ligands in ovarian cancer. Biochim Biophys Acta 1785: 232-265, 2008.

42. Shibata MA, Ambati J, Shibata E, Albuquerque RJ, Morimoto J, Ito $\mathrm{Y}$ and Otsuki Y: The endogenous soluble VEGF receptor-2 isoform suppresses lymph node metastasis in a mouse immunocompetent mammary cancer model. BMC Med 8: 69, 2010. 